\title{
MIR133A1 Gene
}

National Cancer Institute

\section{Source}

National Cancer Institute. MIR133A1 Gene. NCI Thesaurus. Code C81734.

This gene is involved in the regulation of gene expression and plays a role in the development of squamous cell carcinoma. 